\title{
EX-ANTE RISK ESTIMATION IN THE PRODUCTION PROJECT
}

doi: $\quad 10.2478 /$ czoto-2019-0090

Date of submission of the article to the Editor: 05/11/2018

Date of acceptance of the article by the Editor: 07/02/2019

Ewa Kozień ${ }^{1}$ - orcid id: 0000-0002-5876-2804

Marek S. Kozień ${ }^{2}$ - orcid id: 0000-0002-6737-5398

${ }^{1}$ Cracow University of Economics, Poland

${ }^{2}$ Cracow University of Technology, Poland, kozien@mech.pk.edu.pl

Abstract: Identification and evaluation of risk in the production project in the preliminary phase of its realization has important influence on manager's decision about the project continuation, the reduction of project realization or the stop of project realization. The method of the quantitative ex-ante risk estimation in the project is proposed in the paper. The aim of the paper is to blow the whistle on importance of the ex-ante identification and estimation of the risk in the production project, as the factor which has positive influence on the project realization and implementation. In the article the following thesis is proposed: the ex-ante identification and estimation of risk in the project contributes to its efficient realization and increase possibility of obtaining the originally defined results.

Keywords: risk assessment, project

\section{INTRODUCTION}

All activities, including also those which are implemented in a form of projects, always generate risk, what may be perceived in the very essence of a project. Most often, in professional literature, a project is defined as a temporary action undertaken for creation of a unique product or delivering of a unique service (A Guide to the Project Management Body of Knowledge, 2013). Uniqueness means exceptionality of a project in the scope of a concept of the enterprise, however, a level of uniqueness may vary (from a low uniqueness level to high uniqueness level). A characteristic feature of uniqueness of a project is connected to a risk. The more unique a project is, the higher the level of a risk. Risk in a project is connected with occurrence of events which will have realistic impact on a project implementation and its result. These events may have both a positive as well as a negative impact at every stage of the implementation of a project. However, already at an initial stage of preparation of a project, the ex-ante risk assessment in the project may have impact on a decision of project manager on launching or abandonment of a project. Consequences of this decision will not be neutral from the point of view of company development (Kozien, 2017; Kozien and Kozien, 2017).

It is worth emphasizing that a development of modern manufacturing plants as well as strengthening of their competitive position is connected to a development and 
implementation of new innovative products. G.L. Urban and J.R. Houser point out that implementation of new products for companies is risky (Urban and Houser, 1993). In a manufacturing project, a risk is defined by:

- benefits arising from materialization and implementation of a manufacturing project, which may provide increase of profits, contributing to its growth,

- failure in implementation of a new product expressed by losses which may cause a downfall of a company.

This is why identification and ex ante risk assessment are a key problem in management of a manufacturing project, as well as a challenge for managers and project teams, whose tasks is a diagnosis of future events, assessment of probability of their occurrence as well as their potential impact on efficient implementation and assessment of effects for a project. Methods of risk assessment in a project are helpful in identification and ex ante risk assessment in a manufacturing project.

The considered method of a risk assessment seems to be useful in those problems where the knowledge is incomplete (Pietraszek et al., 2017; Lisowski and Filo, 2017; Filo et al., 2018; Krawczyk et al., 2018; Kozien, 2018b) or uncertain (Włodarczyk et al., 2011; Skrzypczak-Pietraszek et al., 2018) while typical methods require data precision unavailable due to a high cost of a real test (Osocha et al., 2004; Osocha, 2018) or other technical problems (Ulewicz et al., 2010; Radzyminska and Ulewicz, 2014; Goroshko et al., 2014). It should be particularly useful in steel and chemical industry management (Ulewicz et al., 2013; Radzyminska-Lenarcik et al., 2018; Maszke et al., 2018).

The purpose of this article is emphasizing of significance of identification and ex ante risk assessment in a manufacturing project as a factor having a positive impact on its materialization and implementation. In the article a following thesis was formed: identification and ex ante risk assessment in a project contributes to its efficient implementation and increases the possibilities of reaching the planned results.

\section{METHODOLOGY OF THE EX ANTE ESTIMATION AND VALIDATION OF THE RISK ON EXAMPLE OF THE PRODUCTION PROJECT}

Problem of identification and risk assessment in a manufacturing project is connected with:

- a situation in which events can occur which may have impact on preparation, implementation and results of undertaken actions in the scope of the implemented project,

- time (moment) of performing assessment (ex ante, on-line, ex post),

- using method/ methods of identification and risk assessment in a project.

In professional literature one may point out to various interpretations of a notion of risk in a project. Kirschbaum, perceiving a positive impact of events on implementation of a project, interprets a notion of risk as all kind of uncertainty, also such one which will beneficially alter a course and effects of a project (Kirschbaum, 2000). Whereas, Żurek defines a risk as an uncertain phenomenon, concerning future, the occurrence of which will have negative effect for project implementation (Żurek, 1999).

However, an appropriate approach for an issue of identification and risk assessment in a project is viewing it in a context of both positive as well as negative impact on its preparation, implementation and results of its activities. Such interpretation of risk in a project is presented by World Project Management Institute defining a risk as 
an uncertainty regarding an occurrence of an event or a condition which, if they appear, will have essentially positive or negative impact on a course of a project (Project Management Institute homepage, 2018). Risk may be also generally defined as a combination of probability of occurrence of an event and its effects (ISO IEC Guide 73:2002, 2002), which may turn out to be a chance or a risk for success of a project (Risk Management Standard, 2003). This is why the identification and risk assessment in a manufacturing project increases the chances for its success and therefore for developmental expansion of a company.

Identification and risk assessment in a project are of practical character and refers to events which are known or which may become known, the probability of occurrence of which or effects of their occurrence may be assessed. The purpose of assessment of risk in a project is minimization of the impact of activities putting the implementation of a project at risk by their ongoing correction. The assessment is defined as a process of systematic examination (Sanders, 1994), which is performed at an initial stage (exante), implementation (on-line) and finishing of a project (ex-post). Sefton et al. (Sefton et. al., 2002) drew their attention to a requirement of development of an Evalsed method in the scope of development of comprehensive methods, both qualitative and quantitative, used for project assessment. Moreover, they pointed out to a need of searching new concepts of assessment of projects, using interdisciplinary approach to risk assessment. Also, they pointed out to an effort of adaptation of interdisciplinary methods for project assessment (Sefton et. al., 2002).

In professional literature one may differentiate comprehensive and fragmentary methods, used for assessment of projects. Well-known methods of assessment of projects include: Feasibility Study, Cost Benefit Analysis, Multi-Criterial Expert Assessment, Cost-Utility Analysis, Economic Impact Analysis, Social Cost Benefit Analysis.

This search also includes proposals of authors of the article, who - in earlier publications - suggested a use of quantitative method based on a notion of a fuzzy logic (Kozień and Kozień, 2018), as well as qualitative method of list of risks for assessment of risk in a project (Kozień, 2018).

Purposes and a course of research. The cognitive purpose of the conducted research was identification and assessment of risk factors which may have impact on a managerial decision on implementation or abandonment of a project. The methodological purpose was development of a method for ex ante risk assessment in a project.

Research methodology included the following stages:

Stage 1 - specification of purpose and subject of research. The purpose of research is ex ante risk assessment in a project. The subject of this research are projects of manufacturing type.

Stage 2 - gathering information on the project means becoming acquainted with specific characteristics of a manufacturing project and gathering of necessary information on a project and risk factors which may have impact on its implementation.

Stage 3 - application of the proposed quantitative method for ex ante risk analysis in a manufacturing project means the assessment according to the risk factors taken into account (Table 1).

Stage 4 - Interpretation of results and formulation of conclusions. 
Identification and ex ante risk assessment in a manufacturing project concerns prediction of factors which may and do not have to materialize, however - their occurrence may have positive or negative impact on the implementation and results of the project. Risk of a project due to the impact factors may be divided into external factors, which define general risk and internal risk, which pertain to project risk (organizational risk, risk connected to project management, technical risk).

Quantitative Analysis. In order to conduct quantitative ex ante risk assessment of a manufacturing project, 21 risk factors were formulated, based on literature research and own experience $(i=1, \ldots, 21)$ including a group of general risk (9 factors) and project risk (12 factors). These factors were gathered in the first column of Table 1. Each of the factors is connected to the quantitative assessment of potential possibility of occurrence of a described risk factor in a project $\left(r_{i}\right)$ evaluated in the 1-3 scale (1low risk, 2 - moderate risk, 3 - high risk) and assessment of effects of occurrence of the considered risk factor $\left(\mathrm{s}_{\mathrm{i}}\right)$ evaluated in the scale 1-6 (1- benign effect, 3-moderate effect, 6 - severe effect). Risk factors are defined for a manufacturing project. Approved method of description including an assessment of possibility of risk occurrence, effects of its occurrence and the approved scales of quantitative assessment together with reference to linguistic description were approved after Pritchard (Pritchard, 2002; Wirkus et. al., 2014). Based on these values a parameter of comprehensive ex ante risk assessment $R$ in project is defined, defining it in a form of (1). This form refers to a method of assessment of risk included in the risk-list method (Kozien, 2018a) and an earlier paper written by Bradley (Bradley, 2003).

$$
R=\sum_{i=1}^{21} \frac{r_{i} s_{i}}{s_{i}}
$$

The obtained value of $\mathrm{R}$ parameter serves for comprehensive ex ante risk assessment in a manufacturing project. Table 1 lists the values of factors of possibilities of risk occurrence $\left(r_{i}\right)$ and effects of risk occurrence $\left(s_{i}\right)$ for an analyzed manufacturing project.

Table 1

Factors for ex ante risk assessment in a manufacturing project.

\begin{tabular}{|c|c|c|c|}
\hline \multicolumn{2}{|r|}{ Risk factors (i) } & $\begin{array}{l}\text { Possibility of } \\
\text { risk occurence }\end{array}$ & Effects $\left(s_{i}\right)$ \\
\hline \multicolumn{4}{|c|}{ General risk factors } \\
\hline 1 & Political changes occurring in the environment & 1 & 3 \\
\hline 2 & Legislative changes & 1 & 1 \\
\hline 3 & Economic changes occurring in the environment & 2 & 6 \\
\hline 4 & Sudden changes in technical progress & 3 & 6 \\
\hline 5 & Impact of external stakeholders & 2 & 3 \\
\hline 6 & Unspecified requirements of a client & 1 & 1 \\
\hline 7 & Gaps in formal requirements of a contract & 1 & 3 \\
\hline 8 & No verified suppliers & 3 & 6 \\
\hline 9 & $\begin{array}{l}\text { Supplier does not have the implemented system } \\
\text { of securing quality }\end{array}$ & 2 & 3 \\
\hline \multicolumn{4}{|c|}{ Project risk factors } \\
\hline
\end{tabular}




\begin{tabular}{|l|l|c|c|}
\hline 10 & $\begin{array}{l}\text { No maturity for a project of a company in the } \\
\text { scope of knowledge management (bases of } \\
\text { knowledge) }\end{array}$ & 2 & 6 \\
\hline 11 & $\begin{array}{l}\text { No maturity for a project of a company in the } \\
\text { scope of applied methods and methodology of } \\
\text { management of projects }\end{array}$ & 1 & 3 \\
\hline 12 & $\begin{array}{l}\text { Inefficient managerial and organizational system } \\
\text { of a company supporting management of a } \\
\text { project }\end{array}$ & 1 & 1 \\
\hline 13 & $\begin{array}{l}\text { Non-formalized standards of human resources } \\
\text { management }\end{array}$ & 1 & 3 \\
\hline 14 & $\begin{array}{l}\text { Non - precise definition of purposes and } \\
\text { requirements of a project concerning the time, } \\
\text { cost and quality) }\end{array}$ & 2 & 3 \\
\hline 15 & $\begin{array}{l}\text { Project is a solution with high degree of } \\
\text { uniqueness }\end{array}$ & 2 & 3 \\
\hline 16 & High technological complexity/new technologies & 2 & 1 \\
\hline 17 & Changes of technical standards & 2 & 3 \\
\hline 18 & $\begin{array}{l}\text { Low quality of project teams (knowledge, } \\
\text { competences, skills) }\end{array}$ & 1 & 3 \\
\hline 19 & No experts & 2 & 1 \\
\hline 20 & Inefficient system of communication & 1 & 3 \\
\hline 21 & Destructive character of conflicts & 1 & 1 \\
\hline
\end{tabular}

Source: own research

\section{RESULTS AND DISCUSSION}

As an example of analysis - a manufacturing project was reviewed, for which the ex-ante risk assessment was performer for value of factors of possibility of risk occurrence $\left(r_{i}\right)$ and effects of risk occurrence $\left(s_{i}\right)$ listed in Table 1 . The value of parameter of comprehensive ex ante risk assessment in a project, obtained on their basis, using form (1) amounts to $R=1.91$, what means a moderate risk of implementation of a project, appointed prior to a commencement of its implementation (accepting the same scale for a description of risk assessment like in a case of risk factors assessment, which was performed earlier). Detailed ex ante risk assessment in a manufacturing project facilitates the indication of factors generating its highest level. For the considered manufacturing project, these are the factors connected with risk referring to changes in the scope of technical progress and the lack of verified business partners (suppliers), as well as economic changes. The listed risk factors constitute a general risk of a project, whereas the lower level of risk is generated by risks referring to a project risk. Therefore it can be concluded that a project potential of a company facilitates the implementation of a project. Identified risk factors are connected with its environment, what in practice means that at a stage of project implementation the risks of environment must be monitored on-line.

\section{CONCLUSIONS}

Implementation of each project is connected with a risk to its successful completion. Therefore, a significant task of any project manager already a tan early stage of a project is indication of areas generating possible risks using methods serving for identification and ex ante risk analysis. 
An advantage of the proposed quantitative method of ex-ante risk analysis in a project is a possibility of expanding a number of assessment criteria and adjusting them for a given type of project. And therefore, an analyzed manufacturing project included technical risk connected with implementation of manufacturing process, whereas in a situation of assessment of the so-called soft project, one should pay more attention to social risks.

Problem of identification and risk assessment in a project is a valid issue concerning the prediction of events which may occur in the future and have impact on management of time and cost in a project. Identification and assessment of risk in a project is a continuous process. Key significance for risk management in a project is its identification and ex ante assessment at an early stage of preparation and monitoring of indicated specific risk factors in subsequent project stages.

\section{REFERENCES}

A Guide to the Project Management Body of Knowledge 5th Edition., 2013. PMI, USA. Bradley, K., 2002. Ken Bradley's understanding PRINCE2. SPOCE Project Management Ltd., Poole, UK.

Filo, G., Lisowski, E., Domagala, M., Fabis-Domagala, J., Momeni, H., 2018. Modelling of pressure pulse generator with the use of a flow control valve and a fuzzy logic controller. MSM 2018: 14th Int. Conf. Mechatronic Systems and Materials, Zakopane, Poland, AIP Conf. Proc., 2029, art. 020015. DOI: 10.1063/1.5066477

Goroshko, A., Royzman, V., Pietraszek, J., 2014. Construction and practical application of hybrid statistically-determined models of multistage mechanical systems. Mechanika, 20, 489-493. DOI: 10.5755/j01.mech.20.5.8221

ISO IEC Guide 73:2002, Risk Management-Vocabulary-Guidelines for Use in Standards.

Kirschbaum, D.M., 2000. Calculated Risk, Good Surprise, Bad Surprise: The Law of Unintended Consequences. Community Risk Management and Insurance, Washington, USA.

Kozien, E., 2017. Identification of stage phase growth in the checklist method using different statistical parameters. $20^{\text {th }}$ International Scientific Conference on Economic and Social Development. Varazdin, Varazdin Development and Entrepreneurship Agency, 538-545.

Kozien, E., Kozien, M., 2017. Interval analysis as a method of measurement of uncertainity in the check-list method applied to identification of stage phase of companies. $26^{\text {th }}$ International Scientific Conference on Economic and Social Development. Varazdin, Varazdin Development and Entrepreneurship Agency, 210-215.

Kozien, E., 2018a. Using the risk-list method for risk assessment in the project. $31^{\text {st }}$ International Scientific Conference on Economic and Social Development. Varazdin, Varazdin Development and Entrepreneurship Agency, 152-158.

Kozien, E., 2018b. Quality of project financed by the European Union structural fund. $12^{\text {th }}$ Int. Conf. "Quality Production Improvement" QPI 2018. MATEC Web of Conferences, 183, art. 04006. DOI: 10.1051/matecconf/201818304006

Kozien, E., Kozien, M., 2018. Using the fuzzy logic description for the ex-ante risk assessment in the project. $35^{\text {th }}$ International Scientific Conference on Economic 
and Social Development. Varazdin, Varazdin Development and Entrepreneurship Agency, 224-231.

Krawczyk, J., Sobczyk, A., Stryczek, J., Walczak, P., 2018. Tests of New Methods of Manufacturing Elements for Water Hydraulics. Mater. Res. Proc., 5, 200-205. DOI: 10.21741/9781945291814-35

Lisowski, E., Filo, G., 2017. Analysis of a proportional control valve flow coefficient with the usage of a CFD method. Flow Meas. Instrum. 53, 269-278. DOI: 10.1016/j.flowmeasinst.2016.12.009

Maszke, A., Dwornicka, R., Ulewicz, R., 2018, Problems in the implementation of the lean concept at a steel works - Case study. MATEC Web Conf., 183, art. 01014. DOI: $10.1051 /$ matecconf/201818301014

Osocha, P., Duda, P., Weglowski, B., 2004. Determining temperature and stress changes in thick-walled elements of steam lines. Inz. Chem. Procesowa 25, 22492256.

Osocha, P., 2018. Calculation of Residual Life for P91 Material Based on Creep Rate and Time to Rupture. Mater. Res. Proc. 5, 177-182. DOI: 10.21741/9781945291814-31

Pietraszek, J., Dwornicka, R., Krawczyk, M., Kołomycki, M., 2017. The nonparametric approach to the quantification of the uncertainty in the design of experiments modelling. UNCECOMP 2017, NTU of Athens, 598-604. DOI: 10.7712/120217.5395.17225

Pritchard, C.L., 2001. Risk management. Concepts and guidance. ESI International, Virginia, USA.

Project Management Institute homepage. http://www.pmi.org [access date: 10.11.2018]

Radzyminska-Lenarcik, E., Ulewicz, M., 2014. The use of 1-alkylimidzoles for selective separation of zinc ions in the transport process across a polymeric inclusion membrane. Physicochem. Probl. Mi. 50, 131-142. DOI: 10.5277/ppmp140112

Radzyminska-Lenarcik, E., Ulewicz, R., Ulewicz, M., 2018. Zinc recovery from model and waste solutions using polymer inclusion membranes (PIMs) with 1-octyl-4methylimidazole. Desalination and Water Treatment, 102, 211-219. DOI: 10.5004/dwt.2018.21826

Sefton T., Byford S., McDaid D., Hills J., Knapp M., 2002. Making the most of it. Economic evaluation in the social welfare field, Joseph Rowntree Foundation, New York, USA.

Sanders, J.R. (chair), 1994. The program evaluation standards: how to assess evaluation educational programs. Sage Publications, Thousand Oaks, California, USA.

Skrzypczak-Pietraszek, E., Piska, K., Pietraszek, J., 2018. Enhanced production of the pharmaceutically important polyphenolic compounds in Vitex agnus castus $L$. shoot cultures by precursor feeding strategy. Eng. Life Sci., 18, 287-297. DOI: 10.1002/elsc.201800003

Ulewicz, M., Lesinska, U., Bochenska, M., 2010. Transport of lead across polymer inclusion membrane with p-tert-butylcalix[4]arene derivative. Physicochem. Probl. Miner. Process., 44(1), 245-256. 
Ulewicz, R., Selejdak, J., Borkowski, S., Jagusiak-Kocik, M., 2013. Process management in the cast iron foundry. METAL 2013: $22^{\text {nd }}$ Int. Conf. Metallurgy and Materials, Ostrava, Tanger, 1926-1931.

Urban G.L., Hauser J.R., 1993. Design and Marketing of New Products, Prentice Hall, Englewood Cliffs, New Jersey, USA.

Wirkus, M., Roszkowski, H., Dostatni, E., Gierulski, W., 2014. Zarządzanie projektem. Polskie Wydawnictwo Ekonomiczne, Warszawa [in Polish].

Wlodarczyk, R., Dudek, A., Nitkiewicz, Z., 2011. Corrosion analysis of sintered material used for low-temperature fuel cell plates. Arch. Metall. Mater. 56, 181-186. DOI: 10.2478/v10172-011-0021-0

Żurek, B., 1999. Risk management with application of assisted software RMS. Proc. $1^{\text {st }}$ Conference "Project Management - Experiences and Methods", Gdańsk, Poland. 